Ks. Andrzej Kuźma

Chrześcijańska Akademia Teologiczna w Warszawie

\title{
Wewnętrzne życie Kościoła prawosławnego w projektach dokumentów dla Soboru Wszechprawosławnego
}

Zwoływanie soboru, czy to w kontekście lokalnym, czy też powszechnym, stanowiło zawsze ważne wydarzenie w życiu i funkcjonowaniu samego Kościoła. Każde zgromadzenie biskupów, które określane jest przez nich samych, jak też przez świadomość kościelną mianem soboru, w ten czy inny sposób nawiązuje do zgromadzenia apostołów, które zostało opisane przez ewangelistę Łukasza w Dziejach Apostolskich (Dz 15, 1-35). Jest ono w swym działaniu nakierowane ku wyjawieniu prawdy Bożej, która złożona jest w Kościele jako swego rodzaju depozyt i która w danym momencie życia Kościoła potrzebuje ujrzenia światła dziennego. Kościół żyje poprzez łaskę Ducha Świętego i to On jest tą siłą, która kieruje Kościołem i prowadzi go na przestrzeni dziejów ${ }^{1}$. Dlatego tak ważnym w dziele funkcjonowania Kościoła i podejmowania decyzji jest stwierdzenie zawarte w Dziejach Apostolskich: „Postanowiliśmy bowiem, Duch Święty i my..." (Dz 15, 28). Sobór Wszechprawosławny,

${ }^{1}$ Zob. M. Afanasjew, Kościół Ducha Świętego, tłum. H. Paprocki, Białystok 2002, szczególnie rozdział VIII Władza Miłości, s. 337-364. 
którego zwołanie przewidziane jest w najbliższym czasie, pozostaje w świadomości współczesnego prawosławia właśnie takim działaniem, które z jednej strony jest kontynuacją starożytnej tradycji Kościoła opartej na zasadzie soborowości, z drugiej zaś jest autentycznym głosem Ducha Świętego, który działa w Kościele i który jest zasadą jego funkcjonowania.

Wśród dziesięciu tematów, które zostały określone przez I Konferencję Wszechprawosławną w 1976 roku², jako najważniejsze zagadnienia, co do których powinien wypowiedzieć się przyszły sobór, znalazły się tematy wyrażające stosunek Kościoła prawosławnego do świata zewnętrznego, jak też zagadnienia odnoszące się do życia wewnętrznego tegoż Kościoła. Do tematów, które odnoszą się do wewnętrznego życia Kościoła należałoby zaliczyć następujące: 1) Zagadnienie kalendarza; 2) Sakrament małżeństwa i przeszkody do jego zawarcia; 3) Znaczenie postu i jego zachowanie dzisiaj; 4) Autonomia i sposób jej ogłaszania; 5) Autokefalia i sposób jej ogłaszania; 6) Dyptychy Kościoła prawosławnego; 7) Diaspora prawosławna. Spośród tych siedmiu tematów tylko cztery zostały opracowane w taki sposób, że obecnie stanowią projekty dokumentów na przyszły Sobór Wszechprawosławny. Są to następujące tematy: 1) Sakrament małżeństwa i przeszkody do jego zawarcia; 2) Znaczenie postu i jego zachowanie dzisiaj; 3) Autonomia i sposób jej ogłaszania; 4) Diaspora prawosławna. Trzy pozostałe tematy: 1) Zagadnienie kalendarza; 2) Autokefalia i sposób jej ogłaszania oraz 3) Dyptychy Kościoła prawosławnego, zgodnie z decyzją podjętą na zgromadzeniu (synaksie) zwierzchników autokefalicznych Kościołów prawosławnych w styczniu 2016 roku, nie wejdą w zakres tematyki, którymi zajmie się najbliższy sobór. Wynika to stąd, że na etapie soborowych przygotowań projekty tych dokumentów nie uzyskały jednoznacznej akceptacji wszystkich lokalnych

2 Zob. Première Conférence Panorthodoxe Préconciliaire [1976], Décisions, [Chambésy, 28 novembre 1976], [w:] Synodica III, s. 114. 
Kościołów ${ }^{3}$ Z pewnością Kościół prawosławny w ten czy inny sposób w przyszłości powróci do opracowania tych zagadnień i nie pozostawi ich bez odpowiedzi. Ponieważ dokumenty te były szeroko dyskutowane zarówno w ramach komisji przygotowawczych, jak też Konferencji Wszechprawosławnych, w niniejszym artykule zostaną nakreślone najważniejsze punkty, które dotykają tych trzech zagadnień.

Dokument mówiący o Sakramencie małżeństwa i przeszkodach do jego zawarcia jest jednym z tekstów, który w swojej pierwotnej wersji został najwcześniej opracowany. Pierwotna wersja tematu była znacząco zawężona i brzmiała Przeszkody małżeńskie ${ }^{4}$. Z biegiem lat okazało się, że nie wystarczy mówić jedynie o przeszkodach w zawarciu związku małżeńskiego, lecz w dobie kiedy instytucja małżeństwa jest podważana na rzecz tzw. wolnych związków lub małżeństw homoseksualnych, należy podkreślić wartość małżeństwa jako sakramentu i ważność instytucji rodziny. Dlatego też na synaksie zwierzchników lokalnych Kościołów prawosławnych w styczniu 2016 roku dokument o przeszkodach w zawarciu związku małżeńskiego został znacząco poszerzony i nieco zmodyfikowany ${ }^{5}$. Tekst podzielony jest na dwie części: 1) Prawosławne małżeństwo i 2) Przeszkody w zawarciu małżeństwa. W części pierwszej podkreśla się wartość rodziny i świętość małżeństwa:

„Instytucja rodziny jest obecnie zagrożona w związku ze zjawiskiem sekularyzacji, jak również relatywizmu moralnego. Kościół prawosławny uznaje świętość małżeństwa za istotny i niezaprzeczalny element swojego

${ }^{3}$ Zob. Komunikat Synaksy Zwierzchników Cerkwi Prawosławnej, Chambésy 21-28 stycznia 2016, „Wiadomości Polskiego Autokefalicznego Kościoła Prawosławnego” (2016) nr 3 (316), s. 5.

${ }^{4}$ Zob. Przeszkody małżeńskie. Tekst przyjęty przez II Wszechprawosławną Konferencję Przedsoborową (Chambésy 1982), [w:] NSO, s. 398-399.

${ }^{5}$ Zob. Le sacrement du mariage et ses empêchements (Chambésy, 27 janvier 2016), https://mospat.ru/fr/2016/01/28/news127389/ (28.01.2016). Tłum. własne. Należy zaznaczyć, że dokument ten w obecnej proponowanej wersji nie został podpisany przez delegację Patriarchatu Antiocheńskiego i Gruzińskiego. 
nauczania. Wolny związek pomiędzy mężczyzną a kobietą jest koniecznym warunkiem małżeństwa" (I, 1).

Dokument w wyraźny sposób zaznacza istnienie we współczesnym świecie tzw. związków partnerskich i określa je jako swego rodzaju zagrożenie:

„Wywierany we współczesnym świecie nacisk na uznanie nowych form partnerstwa jest realnym zagrożeniem dla prawosławnych chrześcijan. Kryzys małżeństwa i rodziny, przejawiający się w różnych formach, głęboko niepokoi prawosławny Kościól, nie tylko z powodu negatywnych konsekwencji w strukturze społeczeństwa, lecz również z powodu zagrożenia dla bardziej specyficznych relacji w łonie tradycyjnej rodziny" (I, 8).

W wyraźny sposób podkreśla się, że Kościół nie może uznawać i udzielać swego błogosławieństwa osobom tej samej płci: „Kościół nie uznaje związków partnerskich jednej płci swoich członków, lub też jakiejkolwiek innej formy partnerstwa innej niż małżeństwo" (I, 10). W dokumencie zwraca się również uwagę i wyraża troskę wobec wzrastającej liczby rozwodów (por. I, 11).

Druga część dokumentu omawia przeszkody w zawarciu małżeństwa. W większości powtórzone zostały te punkty, które zawarte były w dokumencie przyjętym przez II Konferencję Wszechprawosławną (1982). Niektóre z tych punktów zostały nieco zmodyfikowane. Jako pierwsze przeszkody w zawarciu związku małżeńskiego ukazane zostały powody wynikające z pokrewieństwa, powinowactwa i adopcji (por. II, 1). Kolejne to brak unieważnienia poprzedniego małżeństwa lub złożenie ślubów zakonnych. Kategorycznie zabrania się też zawierania związku małżeńskiego osobom, które są w stanie kapłańskim (por. II, 4). Małżeństwo zawarte z chrześcijaninem innym niż prawosławny może mieć miejsce pod pewnymi warunkami. Tym warunkiem jest deklaracja ochrzczenia i wychowania dzieci zrodzonych z tego małżeństwa w wierze prawosławnej ${ }^{6}$. Zabrania się jed-

\footnotetext{
${ }^{6}$ Taka zasada stosowana jest również w Kościele rzymskokatolickim.
} 
nocześnie zawierania związków małżeńskich z niechrześcijanami Na koniec znajdujemy uwagę, która poszczególnym Kościołom lokalnym daje prawo stosowania zasad ekonomii względem wyżej nakreślonych przeszkód:

„Stosowanie ekonomii kościelnej zostaje określone przez Święty Synod każdego autokefalicznego Kościoła prawosławnego, zgodnie z zasadami wynikającymi z kanonów kościelnych, w duchu duszpasterskiej troski o zbawienie człowieka" (II, 7).

Jest to ważne stwierdzenie $\mathrm{z}$ tego względu, że różnice kulturowe i warunki geopolityczne w niektórych Kościołach prawosławnych zasadniczo różnią się od innych. W dyskusjach prowadzonych na ten temat w latach 80. delegacja Patriarchatu Antiocheńskiego zwracała uwagę na to, że związkom małżeńskim prawosławnej osoby z chrześcijaninem nieprawosławnym powinno udzielać się błogosławieństwa, natomiast nie można błogosławić małżeństw osób prawosławnych z niechrześcijanami. $Z$ drugiej strony podkreślano, że związek małżeński prawosławnej osoby z niechrześcijaninem zawarty wobec władzy cywilnej nie może być traktowany jako nieważny. Osoba prawosławna będąca w takim związku nie może być pozbawiona prawa przystępowania do Eucharystii ${ }^{8}$.

Dokument dotyczący postu w swojej początkowej formie został przyjęty na II Konferencji Wszechprawosławnej (1982), a następnie nieco zmodyfikowany na V Konferencji (2015) ${ }^{9}$.

\footnotetext{
${ }^{7}$ Wydaje się, że dokument przyjęty w 1982 roku był mniej rygorystyczny względem zawierania związków małżeńskich z innowiercami lub niechrześcijanami. Pozostawiał więcej swobody lokalnym Kościołom prawosławnym na regulowanie tych spraw przez lokalne synody lub sobory, mając na uwadze troskę pasterską. Por. Przeszkody małżeńskie, dz.cyt., s. 399.

${ }^{8}$ Zob. Synodica VIII, s. 127 .

${ }^{9}$ Por. Cinquième Conférence Panorthodoxe Préconciliaire, Les relations de l'Église orthodoxe avec l'ensemble du monde chrétien. Décision (Chambésy, 15 octobre 2015), maszynopis, 6 stron (w archiwum autora).
} 
W pierwszych słowach tekstu stwierdza się, że post jest dziełem Bożym i jest dobry dla człowieka: „Post jest przykazaniem Bożym (Rdz 2, 16-17) [...]. Stanowi on wielką duchową walkę i jest najlepszym wyrażeniem ascetycznego ideału prawosławia" (nr 1). Wzór właściwej postawy wobec postu dał Pan nasz Jezus Chrystus: „Sam nasz Pan Jezus Chrystus przed rozpoczęciem swojej publicznej działalności, pościł przez czterdzieści dni (Łk 4,1-2) i dał wskazania dotyczące praktyki postu" (nr 2). Post należy rozumieć przede wszystkim w wymiarze duchowym, tzn. powinien on być nieodzownie połączony $\mathrm{z}$ aspektem liturgicznym i pokutą:

„Nierozłączny związek między postem i nabożeństwem ukazuje miarę i cel postu, podkreślając duchowy charakter postu, do którego wezwani są wszyscy wierni, każdy według swych sił i możliwości. [...]. Prawdziwy post, jako zmaganie duchowe, związany jest z ciągłą modlitwą i szczerym żalem" (nr 2-3).

W dokumencie zauważa się, że post jest postrzegany najczęściej jako wstrzemięźliwość od pewnych określonych produktów żywnościowych. Rzeczywiście polega on na wstrzemięźliwości lub ograniczeniu jedzenia, ale ma także wymiar głębszy: „Post jest wstrzemięźliwością od jedzenia, zgodnie ze znaczeniem słowa; jednakże jedzenie nie tworzy nas bardziej poprawnymi czy też mniej poprawnymi. Post posiada głębsze znaczenie" (nr 3). W ten sposób post odnosi się do całości życia w Chrystusie, natomiast w wymiarze liturgicznym w sposób szczególny wyraża się w sakramencie Eucharystii. Wysiłek duchowy związany z postem zalecany jest wszystkim wiernym. Jednocześnie w dokumencie zauważa się, że należy pamiętać również o wyrozumiałości wobec tych, którzy z tej czy innej przyczyny nie wypełniają postu:

„Zgodnie z prawosławnym pojmowaniem duchowego życia, wszystkim zaleca się, aby nie zaniedbywali walki duchowej, jaką jest post, ale jednocześnie pozwalali sobie na pewne odstępstwa, pokładając ufność w miłosierdziu Bożym, patrząc na siebie krytycznie i uświadamiając sobie własną niegodność" (nr 5). 
Tradycja prawosławna ustanowiła kilka okresów postów, które zaleca wypełniać również dzisiaj. Ponadto istnieją posty jednodniowe, związane z obchodzeniem pewnych wydarzeń biblijnych. Dlatego też zaleca się wypełnianie następujących postów:

„Wielkiego Postu, środy i piątku, potwierdzonych przez święte kanony, zarówno postów przed Bożym Narodzeniem, uroczystości Świętych Apostołów (Piotra i Pawła), Zaśnięcia Dziewicy, jednodniowych postów w Podwyższenie Krzyża Pańskiego, w wigilię Epifanii i Ścięcia Jana Chrzciciela, jak również postów ustanowionych ze względów duszpasterskich lub dobrowolnie podejmowanych przez wiernych" (nr 6).

W dokumencie nie zostały zdefiniowane i ukazane konkretne produkty żywnościowe, których nie zaleca się spożywać w czasie postu lub które można spożywać. W tej kwestii zachęca się, by słuchać się tradycji, ale również stwierdza się, że każdy Kościół lokalny według swoich warunków klimatycznych i geograficznych może samodzielnie rozwiązywać powyższe problemy (zob. nr 7). Ważną rzeczą, na którą zwraca się uwagę, jest wymóg zachowywania ścisłego postu przed Eucharystią (por. nr 9). Pościć należy również na znak pokajania oraz przed ważnymi wydarzeniami duchowymi, jak na przykład chrzest czy święcenia kapłańskie; ponadto post może być wyrazem nałożonej epitemii (pokuty) (zob. nr 9). Ogólnie tekst raczej nie ujmuje zagadnienia postu w kategoriach jurydycznych czy też obowiązku. W kontekście wypełniania postu najczęściej używa się w nim zwrotów „zaleca się" lub „zachęca się”. Nie ma też mowy o ewentualnym grzechu z powodu niewypełniania postu.

Dokument dotyczący Diaspory prawosławnej został opracowany przez Komisję Przygotowawczą już w 1993 roku. Natomiast w 1995 roku został opracowany Regulamin Zgromadzeń Biskupów. Oba teksty stały się obiektem dyskusji i po naniesieniu poprawek ostatecznie zostały przyjęte przez IV Konferencję Przedsoborową w 2009 roku $^{10}$. Temat ten jest

${ }^{10}$ Zob. Quatrième Conférence Panorthodoxe Préconciliaire, La diaspora orthodoxe. Décisions, [w:] Synodica XII, s. 256-260; Quatrième Conférence Panorthodoxe 
jednym z najbardziej żywych i aktualnych zagadnień prawosławia we współczesnym świecie. Dotyczy mianowicie funkcjonowania diecezji i parafii prawosławnych na terytoriach, na których prawosławie pojawiło się w wyniku migracji ludności, takich jak: Europa Zachodnia, Ameryka, Australia i in. W wyniku tejże migracji powstawały diecezje o tradycji greckiej, rosyjskiej, rumuńskiej, serbskiej i innych. W konsekwencji takiego naturalnego rozwoju okazało się, że w jednym mieście przebywa jednocześnie kilku prawosławnych biskupów, miedzy którymi brak jest współpracy i koordynacji działań. Taki stan rzeczy stwarzał i nadal stwarza, oprócz problemów organizacyjnych, również sytuację niekanoniczną, biorąc pod uwagę 8. kanon I Soboru Powszechnego, mówiący o tym, że w jednym mieście powinien być jeden biskup ${ }^{11}$. Dokument o diasporze jasno wyraża pogląd, że zagadnienie to potrzebuje jak najszybszego rozwiązania:

„Wszystkie święte Kościoły prawosławne wyrażają zgodnie wolę, aby problem diaspory został rozwiązany możliwie jak najszybciej i by została ona zorganizowana zgodnie z wymogami prawosławnej eklezjologii i tradycji, jak też praktyką kanoniczną Kościoła prawosławnego" (nr 1a).

Tym samym wskazuje się, że propozycje zawarte w dokumencie nie rozwiązują całkowicie tego zagadnienia, ponieważ w obecnej sytuacji nie jest to możliwe:

„Na obecnym etapie nie jest możliwe z powodów historycznych i pastoralnych natychmiastowe przejście do właściwego porządku kanonicznego Kościoła odnośnie do tego zagadnienia, tzn. że w jednym miejscu powinien być tylko jeden biskup. Dlatego też [Konferencja] doszła do wniosku, że należy stworzyć sytuację przejściową, która przygotuje grunt dla rozwiązania czysto kanonicznego tego problemu [...]" (nr 1b).

Préconciliaire, Règlement de fonctionnement des Assemblées épiscopales dans la diaspora orthodoxe, [w:] Synodica XII, s. 261-265. Zob. także A. Kuźma, IV Konferencja Przedsoborowa, WPAKP 2009, nr 7-8 (236-237), s. 4-5.

${ }^{11}$ Zob. Kanony Kościoła Prawosławnego, tłum. A. Znosko, Hajnówka 2000, s. 37 
Ta sytuacja przejściowa, o której mowa jest w dokumencie, ma polegać miedzy innymi na utworzeniu Zgromadzeń Biskupów na tzw. terenach diasporalnych. W skład Zgromadzenia na danym terytorium mają wchodzić wszyscy kanoniczni biskupi różnych jurysdykcji Kościoła prawosławnego związani z lokalnymi autokefalicznymi Kościołami prawosławnymi, których kanoniczność nie budzi wątpliwości. Dokument określa również zadania tych Zgromadzeń:

„Zadaniem i odpowiedzialnością Zgromadzeń Biskupich będzie dbanie o okazywanie jedności prawosławia i rozwijanie wspólnych działań wszystkich wiernych każdego regionu, aby odpowiedzieć na potrzeby pastoralne prawosławnej ludności mieszkającej w regionie, wspólnie reprezentować wszystkich prawosławnych wobec innych wyznań i całej społeczności regionu [...]" (nr 2c).

Proponuje się utworzenie dwunastu takich okręgów, które są nazwane „regionami” na terenach diasporalnych: 1) Ameryka Północna i Ameryka Centralna; 2) Ameryka Południowa; 3) Australia, Nowa Zelandia i Oceania; 4) Wielka Brytania i Irlandia; 5) Francja; 6) Belgia, Holandia i Luksemburg; 7) Austria; 8) Włochy i Malta; 9) Szwajcaria i Liechtenstein; 10) Niemcy; 11) kraje Skandynawskie (z wyjątkiem Finlandii); 12) Hiszpania i Portugalia (zob. nr 3) ${ }^{12}$.

Uzupełnienie dokumentu o diasporze stanowi wspomniany już Regulamin Zgromadzeń Biskupich. Regulamin również był obiektem dyskusji i kontrowersji. Główne dyskusje toczyły się wokół tego, kto powinien przewodniczyć tym Zgromadzeniom. Regulamin precyzuje to zagadnienie, stwierdzając, że „przewodniczącym zostaje z urzędu

${ }^{12}$ Wcześniejsze propozycje Komisji Przygotowawczej (1993) uwzględniały utworzenie ośmiu regionów: 1) Ameryka Północna i Ameryka Centralna; 2) Ameryka Południowa; 3) Australia; 4) Wielka Brytania; 5) Francja; 6) Belgia i Holandia; 7) Austria i Włochy; 8) Niemcy. Zob. Межправославная Подготовительная Комиссия Святого и Великого Собора Православной Церкви, 7-13 ноября 1993 г. (maszynopis), Шамбези-Женева 1994, s. 218-219 (w archiwum autora). Sytuacja Kościoła stała się na tyle dynamiczna, że w 2009 roku uważano za właściwe zwiększenie liczby regionów. 
pierwszy spośród hierarchów Patriarchatu Ekumenicznego, a w razie jego nieobecności kolejny według porządku dyptychów..." (art. 4, nr 2). Decyzje, które są podejmowane, powinny wyrażać konsensus Zgromadzenia (art. 10, nr 1). Zniesienie istniejącego Zgromadzenia Biskupów lub ustanowienie nowego regionu leży w gestii synaksy zwierzchników Kościołów prawosławnych.

Dokument dotyczący Autonomii i sposobu jej ogłaszania należy również do zagadnień, które stanowią żywą potrzebę współczesnego prawosławia. Dokument ten został przyjęty na V Konferencji Przedsoborowej w 2015 roku. Autonomia jest częściową samodzielnością Kościoła na określonym terytorium kanonicznym względem Kościoła Matki tj. względem Kościoła autokefalicznego. Takie sformułowanie znalazło się na początku omawianego dokumentu:

„Instytucja autonomii wyraża w sposób kanoniczny status relatywnej lub częściowej niezależności jakiejś części jurysdykcji kanonicznej od autokefalicznego Kościoła, któremu ta część kanonicznie podlega" (nr 1).

Nadawanie autonomii dla określonego terytorium kościelnego leży w gestii Kościoła Matki. Oznacza to w praktyce, że jeśli określona część Kościoła autokefalicznego pragnie większej niezależności i samodzielności, to z taką prośbą zwraca się do soboru lub synodu tegoż Kościoła. Dalszą procedurę opisuje dokument następująco:

„Po otrzymaniu takiej prośby Kościół autokefaliczny na synodzie ocenia jej przesłanki i przyczyny i przyjmuje postanowienie o nadaniu lub nienadaniu autonomii. W przypadku pozytywnego rozpatrzenia zostaje wydany odpowiedni tomos, określający terytorialne granice Kościoła autonomicznego i jego stosunki z Kościołem autokefalicznym, któremu podlega, zgodnie z ustalonymi kryteriami tradycji kościelnej” (nr 2b).

Następnie zwierzchnik Kościoła autokefalicznego powiadamia patriarchę ekumenicznego i pozostałe Kościoły autokefaliczne o nadaniu autonomii dla danego terytorium. Nowy Kościół autonomiczny w swoich kontaktach wszechprawosławnych i międzykonfesyjnych działa zawsze poprzez Kościół autokefaliczny. Autonomia danego 
Kościoła może być realizowana na różnych poziomach. Chodzi o wybór zwierzchnika danego Kościoła czy też inne zagadnienia o charakterze kanonicznym. Kryteria te powinny znaleźć się w tomosie o nadaniu autonomii. Nadawanie autonomii może odbywać się jedynie w granicach terytorium danego Kościoła autokefalicznego. Nie może zaś odbywać się na tzw. terytoriach diasporalnych, z wyjątkiem sytuacji szczególnych. Czytamy w dokumencie:

„Na terytorium prawosławnej diaspory Kościoły autonomiczne mogą być ustanawiane tylko w przypadku ogólnoprawosławnej zgody koordynowanej przez patriarchę ekumenicznego, zgodnie z ogólnoprawosławną procedurą" (nr 2e).

W przypadku kiedy powstaje Kościół autonomiczny na terytorium należącym do dwóch jurysdykcji, potrzebna jest zgoda i porozumienie tych dwóch Kościołów. Jeśli tego porozumienia nie ma, należy zwrócić się o pomoc w rozstrzygnięciu problemu do patriarchy ekumenicznego (zob. nr 2f). Ponadto zaznacza się, że imię zwierzchnika Kościoła autonomicznego nie funkcjonuje w dyptychach wszechprawosławnych. Kościół ten otrzymuje miro od Kościoła Matki.

Trzy inne zagadnienia, które od początku procesu przygotowawczego stanowiły integralną część katalogu tematów, nie wejdą w obręb dyskusji soborowych, ze względu na brak konsensusu na etapie przygotowawczym odnośnie do ich projektów: 1) Zagadnienie kalendarza; 2) Autokefalia i sposób jej ogłaszania oraz 3) Dyptychy Kościoła prawosławnego. Historia tematu „Zagadnienie kalendarza" jest nieco inna od dwóch pozostałych tematów, z tego względu, że projekt takiego dokumentu był przygotowany i przyjęty przez II Konferencję Przedsoborową w 1982 roku $^{13}$. Jednak zgromadzenie (synaksa) zwierzchników lokalnych Kościołów autokefalicznych w 2014 roku zakwalifikowało ten tekst do nieznacznego przeredagowania ${ }^{14}$. W rezultacie spotkań Komisji Specjalnej, która została

${ }^{13}$ Tekst dokumentu zob. NSO. s. 400-401.

${ }^{14}$ Zob. Decyzja Zwierzchników Cerkwi Prawosławnych, WPAKP 2014, nr 4 (293), s. 3 
powołana przez wspomnianą synaksę zwierzchników, stwierdzono, że dokument ten potrzebuje nie tyle niewielkiej redakcji, lecz gruntownego przeformułowania ${ }^{15}$. Z powodu braku czasu Komisja nie zajęła się więc tym zagadnieniem.

Tematy „Autokefalia i sposób jej ogłaszania”, jak też „Dyptychy Kościoła prawosławnego" były podejmowane niejednokrotnie przez Komisje Przygotowawcze. Rezultaty podjętych decyzji zostały ukazane w przyjętych i podpisanych dokumentach przez Międzyprawosławną Komisję Przygotowawczą, która obradowała w dniach 21-27 lutego 2011 roku w Chambésy ${ }^{16}$. Kościół prawosławny obejmuje szereg Kościołów autokefalicznych, gdzie formą samodzielności w podejmowaniu decyzji i regulowaniu wewnętrznego życia pozostaje zasada autokefalii. W ten sposób przyjęcie pewnych norm dotyczących autokefalii jest jednym z ważniejszych zagadnień eklezjologicznych w prawosławiu. W rezultacie wieloletnich przygotowań zgodzono się, że w nadawaniu autokefalii bierze udział cały Kościół prawosławny. Najważniejszą jednak rolę odgrywają Kościół Matka oraz Patriarchat Ekumeniczny. Podpisanie tomosu o nadaniu autokefalii powinno natomiast mieć miejsce przy współudziale pozostałych zwierzchników lokalnych Kościołów prawosławnych. W tym wypadku to właśnie problematyka związana z podpisywaniem tomosu o autokefalii stanowi największy problem ${ }^{17}$.

Temat dotyczący dyptychów prawosławnych z pozoru może wydawać się błahy. Dotyczy jednak pewnych kryteriów historyczności danego Kościoła, jak też jego znaczenia we współczesnym świecie prawosławnym i porządku, jaki zakłada prawo kanoniczne. Wydaje się właśnie, że ten problem leży u podstaw określenia jednolitego dyptychu dla całego prawosławia. Najważniejsze problemy wiążą

${ }^{15}$ Zob. A. Kuźma, Trzecie spotkanie komisji przygotowawczej, WPAKP 2015, nr 5 (306), s. 7.

${ }^{16}$ Zob. Commision interorthodoxe préparatoire au saint et Grand Concile, Chambésy, 21-27 fevrier 2011, Actes-Documents, maszynopis (w archiwum autora).

17 Zob. Signature di Tome d'autocéphalie, [w:] Commision interorthodoxe préparatoire au saint et Grand Concile, Chambésy, 21-27 fevrier 2011..., dz. cyt., s. 275. 
się z miejscem Patriarchatu Gruzińskiego, który domaga się uznania na forum wszechprawosławnym miejsca szóstego (po Patriarchacie Moskiewskim). Dyskutowaną kwestią jest też miejsce Kościoła cypryjskiego, który w obecnym dyptychu, zajmuje dziesiąte miejsce i jest usytułowany tuż po patriarchatach. Natomiast wolą tego Kościoła, ze względu na jego historyczność, jest zajęcie miejsca „bardziej godnego"18. W kontekście dyskusji o dyptychach pojawia się też wątek miejsca Kościołów polskiego i albańskiego. Jednak w tym przypadku sugestia Komisji brzmi jednoznacznie:

„Międzyprawosławna Komisja Przygotowawcza przeanalizowała prośby Kościołów polskiego i albańskiego, odnośnie do jednolitej pozycji w świętych dyptychach wszystkich lokalnych autokefalicznych Kościołów prawosławnych, przydając pierwszeństwo Kościołowi polskiemu, i proponuje taką adaptację w tychże dyptychach prawosławnych" ${ }^{19}$.

Cztery opracowane w formie projektów tematy na Sobór Wszechprawosławny, które zostały krótko omówione, stanowią ważne osiągnięcie w życiu i funkcjonowaniu Kościoła prawosławnego. Są one swego rodzaju wstępem do opracowania dalszych zagadnień. Natomiast trzy tematy, które nie zostały opracowane, pozostają ważnymi kwestiami dla całego prawosławia i z pewnością powrócą w ten czy w inny sposób na for um debaty ogólnoprawosławnej, po to, by zostało wyrażone wspólne stanowisko całego Kościoła w odniesieniu do tych kwestii.

\section{Bibliografia}

Afanasjew M., Kościół Ducha Świętego, tłum. H. Paprocki, Białystok 2002.

Cinquième Conférence Panorthodoxe Préconciliaire, Les relations de l'Église orthodoxe avec l'ensemble du monde chrétien. Décision (Chambésy, 15 octobre 2015), maszynopis, 6 stron (w archiwum autora).

${ }^{18}$ Zob. Les Diptyques orthodoxe, $\mathrm{nr} 4 \mathrm{ab}$, [w:] Commision interorthodoxe préparatoire au saint et Grand Concile, Chambésy, 21-27 fevrier 2011..., dz. cyt., s. 280.

19 Tamże, nr 3 (tłum. własne). 
Commision interorthodoxe préparatoire au saint et Grand Concile, Chambésy, 2127 fevrier 2011. Actes-Documents, maszynopis (w archiwum autora).

Kanony Kościoła Prawosławnego, tłum. A. Znosko, Hajnówka 2000.

Kałużny T., Nowy sobór ogólnoprawosławny. Natura, historia przygotowań, tematyka, Kraków 2008 [=NSO].

Kuźma A., IV Konferencja Przedsoborowa, WPAKP 2009, nr 7-8 (236-237), s. 4-5.

Kuźma A., Trzecie spotkanie komisji przygotowawczej, WPAKP 2015, nr 5 (306), s. 7.

Komunikat Synaksy Zwierzchników Cerkwi Prawosławnej, Chambesy 21-28 stycznia 2016, WPAKP 2016, nr 3 (316), s. 5.

Les Diptyques orthodoxe, [w:] Commision interorthodoxe préparatoire au saint et Grand Concile, Chambésy, 21-27 fevrier 2011. Actes-Documents, maszynopis, s. 279283.

Le sacrement du mariage et ses empêchements (Chambésy, 27 janvier 2016), https://mospat.ru/fr/2016/01/28/news127389/ (28.01.2016).

Межправославная Подготовительная Комиссия Святого и Великого Собора Православной Церкви, 7-13 ноября 1993 г., Шамбези-Женева 1994, maszynopis (w archiwum autora).

Première Conférence Panorthodoxe Préconciliaire [1976], Décisions, [Chambésy, 28 novembre 1976], [w:] Synodica III, s. 113-117.

Przeszkody małżeńskie. Tekst przyjęty przez II Ogólnoprawosławną Konferencję Przedsoborową (Chambésy 1982), [w:] NSO, s. 398-399.

Quatrième Conférence Panorthodoxe Préconciliaire, La diaspora orthodoxe. Décisions, [w:] Synodica XII, s. 256-260.

Quatrième Conférence Panorthodoxe Préconciliaire, Règlement de fonctionnement des Assemblées épiscopales dans la diaspora orthodoxe, [w:] Synodica XII, s. 261-265.

Signiature du Tome d'autocéphalie, [w:] Commision interorthodoxe préparatoire au saint et Grand Concile, Chambésy, 21-27 fevrier 2011. Actes-Documents, maszynopis, s. 275-278.

Synodica III. Première Conférence Panorthodoxe Préconciliare. [Procès-verbaux et textes], Chambésy, 21-28 novembre 1976, Chambésy (Genève) 1979 [=Synodica III].

Synodica VIII. Deuxième Conférence Panorthodoxe Préconciliaire. [Procès-verbaux et textes], Chambésy, 3-12 septembre 1982, Chambésy (Genève) 1994 [=Synodica VIII]. 


\section{Interior Life of the Orthodox Church Reflected in the Draft Documents of the Pan-Orthodox Council}

\section{SUMMARY}

This article analyzes four topics concerning the internal life of the Orthodox Church which have been accepted as draft documents of the Pan-Orthodox Council. These include: 1) Canonical Impediments to Marriage, 2) The Importance of Fasting and its Practice Today, 3) Autonomy and its Declaration, and 4) Orthodox Diaspora. Three additional topics concerning the life of the Orthodox Church: 1) The Calendar Issue, 2) Autocephaly and its Manner of Declaration, and 3) Diptychs of the Orthodox Church were not accepted as draft documents of the Pan-Orthodox Council, however the author briefly presents their thematic scope and complexity.

KEYWORDS: Pan-Orthodox Council, Orthodox Church, Autocephaly, Autonomy, Diptychs, Calendar, Marriage, Fasting

SŁOWA KLUCZOWE: Sobór Wszechprawosławny, Kościół prawosławny, autokefalia, autonomia, diaspora, dyptychy, kalendarz, małżeństwo, post 